\title{
Oral Ornaments: An Overview
}

\section{RAJNEESH PARIMOO* (D), BALJEET SINGH², DIVYA SHARMA³, VANSHIKA SHARMA³, AQUIB JAVAID4}

Nowadays, people desire to look attractive and have become very alert about their appearance and smile. Since the face is most exposed part of our body, and mouth a prominent feature, teeth are getting enormous share of attention. Intraoral jewellery has currently gained popularity and is slowly becoming a craze, but this fashion trend is also associated with some significant health issues. These ornaments though are said to enhance beauty cause problems such as increase pain, infection, scar formation, tooth fractures, metal hyper-sensitivity reactions, localized periodontal disease, speech impediment, and nerve damage. This review draws special attention to the prevalence, complications, and side effects of dental jewellery in humans. Here we suggest people must be aware of all the risks associated with wearing dental jewellery, and they should undergo dental check-ups regularly.

\section{KEYWORDS: Esthetics, Oral health, Dentistry, Hygiene}

\section{INTRODUCTION}

There is an old saying that when you smile, the entire world smiles with you. Having a beautiful smile is as important as being confident. Tooth jewellery is the latest thing in dentistry which may be used to make someone's smile more alluring. Tooth jewellery is placed on to the tooth surface via dental procedure; this process is known with name of tooth piercing. Nowadays, tooth jewels are gaining attention because substantial number of people are concerned about the way they look. Tooth jewels are adding some spark to their appearance. ${ }^{1}$ Different type of shapes; colours of stone are available to suit the zest of the person. The varied oral jewellery practiced today are grill jewellery, dazzlers and twinkles, veneer jewellery, tooth rings, tongue studs, lip studs, lip rings, cheek studs, etc. Tooth jewellery was in use earlier as an element of the religious rituals and traditions, but today it's more targeting cosmetic function. ${ }^{2}$

Literature describes various short-term and long-term effects related to oral piercings on oral and general health. Gingival recession was the foremost persistent complication which is followed by tooth fracture and periodontal problems. Case report studies have also showed embedding of the piercing and prolonged bleeding after piercing. Endocarditis, infection/or abscess, and ingested piercing can be harmful for general health. ${ }^{3}$ Sometimes improperly placed dental jewels leads to unbearable post-procedure irritation and even could result into loss of tooth. Thus, it could be said that oral piercings do involve some risk. ${ }^{3}$

It's important to find out the prevalence of oral and/or peri-oral piercings to estimate the impact of this phenomenon on every day clinical practice; especially for the dental health care professional. ${ }^{4}$ The aim of this review is to see the various types, prevalence, complications, and side effects of oral ornaments.

\section{HISTORICAL BACKGROUND}

Body piercing has been practiced in ancient times too. Piercings are found on preserved bodies of individuals who lived between 4000 and 5000 years ago. ${ }^{5}$ The Mayans pierced their tongue to demonstrate virility and courage as well. ${ }^{6}$ Recent analysis of thousands of teeth examined from collections in Mexico's national institute of anthropology and history, showed that ancient people of southern North America visited the dentists to beautify their choppers with notches, grooves, and semiprecious gems. ${ }^{7}$ Body piercing is trending among people of different regions, social groups, ages. A survey conducted in western cultures over oral body modifications reported that oral piercing was limited to lip. (i.e. lip stud or labret); lip piercings are often placed anywhere near the vermilion border. ${ }^{6}$ However, even now during this present era, people use dental jewellery while visiting parties, ceremonies or any event. Many of the people have chosen dentistry as mean to reinforce their living style more fashionable. ${ }^{7}$

(C) Rajneesh Parimoo et al. This is an open access article distributed under the terms of the Creative Commons Attribution License CC-BY-NC 4.o, which permits unrestricted use, distribution and reproduction in any medium, provided the use is not commercial and the original author(s) and source are cited. 


\section{TYPES OF ORAL ORNAMENTS}

Grill Jewellery: The interest the grills draw to the mouth is reflective of the importance of vocal dexterity within the African American community. They are made up of gold, silver or platinum, and are sometimes decorated with precious stones and cover the maxillary and mandibular anterior teeth. Earlier, they were fitted permanently after tooth preparation but nowadays grills are generally removable (figure 1$){ }^{8}$ Grills have become so usual that one can purchase a grill anywhere, from the local mall to the online shopping. Some Internet-based companies even send purchasers a home kit that consists of a 2-part putty and impression trays. ${ }^{9}$

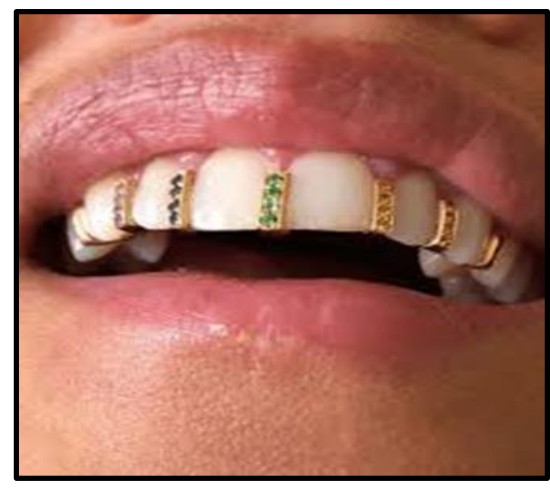

Figure 1. Handmade and Customized to Fit Grill Jewellery

Dazzlers and Twinkles: Most frequently they comprise an additional thin multi carat gold coating, crammed with special glass or precious stones. This incorporates ordinary stones to diamonds and other gems. The stones are attached directly or embedded in a precious metal and then attached to teeth. The metals on which the stones are attached are available in various shapes and sizes. The normal stones are available in various colors. ${ }^{10}$ The enamel is etched and then the stones are luted with flowable composites and no tooth preparation is involved. The foremost liked stone is the white coloured one and the tooth often preferred is the maxillary anterior teeth. However, maxillary lateral incisor is often selected among other teeth and the stones are placed towards the incisal edge. $^{2}$

Tooth Gems: A tiny rhinestone jewel attached to the tooth surface with the help of an adhesive. Some are small stones within the centre of the tooth, other times individuals pick to put a jewel-encrusted cap over their teeth. Tooth gems are available in several colors (figure. 2). No quite teeth preparation is required for these accessories, just etching and bonding is sufficient." There also are removable gems available. These are when the stones are arranged on an invisible glass like microskin. This is, in turn, fabricated within the laboratory to which the precious stones are attached. They can be removed by the individual and fitted when necessary. ${ }^{12}$

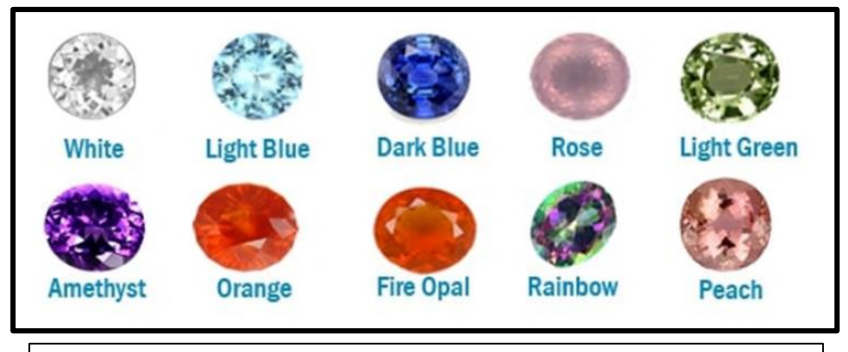

Figure 2. Tooth Gems Available in Different Colours

Tooth Rings: This requires tooth preparation. A tiny hole is made towards the disto-incisal corner of the maxillary incisors and therefore the ring is hung down through it. The maxillary central incisors are the foremost commonly preferred teeth. The dimensions of the perforation depend on the thickness of the ring selected. The perforation should be prepared as smoothly as possible and polished. Sometimes these rings are embedded with precious stones. ${ }^{2}$ The overjet available should even be taken into consideration when selecting the diameter of the ring to avoid interference in occlusion. The rings are sometimes made connecting the two central incisors or the central incisor to the lateral incisor. ${ }^{10}$

Tooth Tattoos: Tooth tattoos are the latest form of art, where hand painted craft is placed onto one's tooth. Typically tooth tattoos are applied to a replacement crown before it's inserted into one's mouth, although the method is also possible with an intentionally removed tooth. This term is additionally used for temporary decals and stains used to decorate the teeth. Dental tattoos can potentially be applied to any tooth, and that they run a large gamut of designs, colours and styles. ${ }^{13}$

Oral Tissue Piercing: Oral piercing sites for jewellery placement include the lips, cheeks, frenum, and uvula. However, the foremost common site for oral piercing is the tongue. Piercings that are most often applied within the oral and perioral areas are captive - bead ring, labret and barbell. ${ }^{14}$ 
The predilected area of the piercing within the mouth are the lips and tongue, followed by the cheeks, uvula and lingual frenulum. ${ }^{15}$ Personnel performing piercing are usually unlicensed and unprofessional with little knowledge on the local anatomy, sterilization procedures, subsequent complications and their management. In such a case the situation is also challenging. ${ }^{16}$

\section{COMPLICATIONS ASSOCIATED WITH ORAL ORNAMENTS}

Well known complications linked to tooth jewellery are discussed below so as to aware the people, because now-a-days most of the people are recommended to use tooth jewellery so as to reinforce their aesthetics and to enhance the self-worth and self-esteem additionally, but there are certain complications related to it. Because of that tooth jewellery is extremely recommended only in those patients who specifically take care of their oral hygiene. Complications of dental jewellery are elaborated by different researchers, can be categorised as acute (or early) and late (or chronic). ${ }^{17}$

Acute complications: Acute complications related to oral jewellery includes post-operative pain, bleeding because of damage to the blood vessels, tearing of the surrounding tissues, metal allergy, alteration in taste due to nerve damage, speech and mastication problems and generation of galvanic current between the accessories and dental restorations..$^{12,18,19}$

Chronic complications: Dental trauma is more often seen with longer jewellery and is related to longer duration of damage. Replacing jewellery with shorter ones may reduce the intensity of injury. ${ }^{16,17}$ Chronic complications include trauma to the gingiva or mucosa (figure 3), fractured or chipped teeth, increased accumulation of plaque and calculus causing infection, gingival recession, allergy, scarring, localized tissue overgrowth, obstruction while taking $\mathrm{X}$-rays for complete examination and aspiration of the jewel or a component of it causing airway obstruction. ${ }^{16}$ Oral jewellery may obstruct during intubation procedure. Ultrasound, CT and MRI images could also be hindered by metal jewellery. Piercing is additionally related to the danger of transmission of blood borne diseases like HIV, Hepatitis B, C, D and G, Herpes simplex, Epstein Barr virus, tetanus, syphilis or tuberculosis. $^{20,21}$ Bacterial infections with
Staphylococcus aureus and Pseudomonas aeruginosa, $\beta$-hemolytic streptococcus have also been reported. ${ }^{22}$

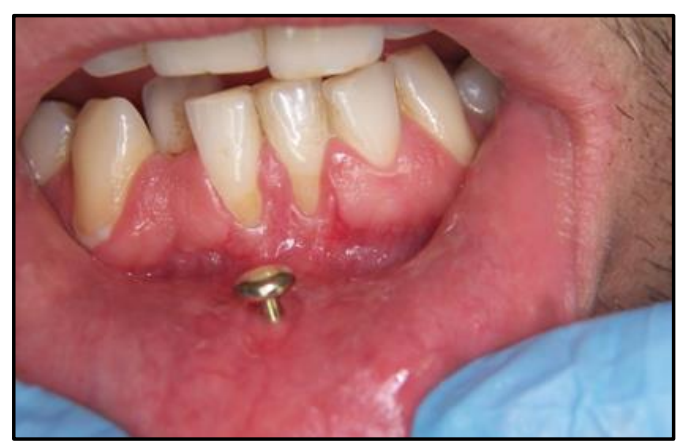

Figure 3. Gingival Recession Caused by Back of Lip Piercing Jewellery

\section{DISCUSSION}

Aesthetics has become a very important feature of dentistry over the recent years and has led to the buildout of recent materials and techniques. Everybody wishes to form their own visual style which makes them unique and yet identifiable among the group. ${ }^{23}$ Body art once viewed as a stigmatized behaviour is now embraced by the youth as a part of fashion and self-expression. Recent days have seen the entry of such practices even into the mainstream community that has professionals, athletes, college students and actors. Several reasons are cited behind this practice. The necessity for feeling unique and selfidentity are the prime reasons (figure 4). ${ }^{24}$ Teenagers and young adults want to precise their individuality in a very simple desire, some people consider it sort of a test of courage and endurance of pain or a variety of provocation and challenge to society, other see it sort of a fashion. ${ }^{14}$ People belonging to any or all age groups are being interested in this type of body art but most typically, it's worn by 18-35 year old hip-hop artists and disc jockeys so as to add on to the extravagance of their performance and to urge an additional spark to their smile while interacting with the audience. ${ }^{2}$ Jewellery used for piercing are usually made of metals like stainless-steel, 14 or 18 karat gold, niobium, titanium, platinum, palladium or metal alloy. Recently synthetic materials like teflon, nylon or plastic are used. Studs, rings and bar bells are commonly used. Dimensions of the jewellery relies on the tissues to be pierced and personal choice. ${ }^{16}$ It's possible for people with jewellery within the oral and perioral regions to experience problems like pain, infection at the 


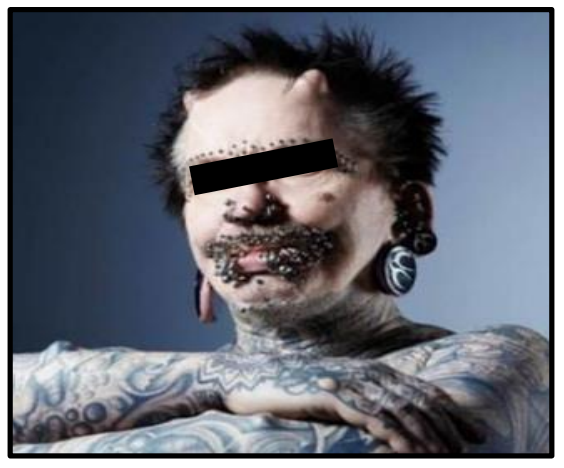

Figure 4. Man Gets in Guinness Book of World Records for the Maximum Number of Body Piercings

location of the piercing, transmission of systemic infections, endocarditis, oedema, airway problems, aspiration of the jewellery, allergy, bleeding, nerve damage, cracking of teeth and restorations, trauma of the gingiva or mucosa, and Ludwig's angina, as well as changes in speech, mastication and swallowing, or stimulation of salivary flow. ${ }^{25}$ Staying updated with current trends that affect the mouth will contribute toward comprehensive care for those served.

\section{CONCLUSION}

Dental jewellery has evolved an extended way from the prehistoric times and is here to remain. It's important for dental professionals to be geared to the changing times and keep themselves updated to be able to cater to and satiate the aesthetic needs of the individuals. It must even be understood that within the world of dental jewellery, the road between aesthetics and potential risks are often very thin. Given the risks related to invasive ornaments like piercings, it's highly recommended that individuals should possess sound knowledge of frequent complications of defects caused by piercing an ornament within the mouth and are advised for correct oral hygiene maintenance and regular dental check-up.

\section{REFERENCES}

1. Vazhiyodan A, Mohan S, VizhiGk, Khan R. Sparkling smile. J I Dent. 2013;1(1):1-3.

2. Peter T, Titus S, Francis G, Alani M, George AJ. Ornamental Dentistry- an overview. Journal of evolution of medical and dental sciences 2013;2(7):666-76.

3. Hennequin-Hoenderdos NL, Slot DE, Van der Weijden GA. Complications of oral and peri-oral piercings: a summary of case reports. Int J Dent Hyg. 2011;9:101-9.
4. Hennequin-Hoenderdos NL, Slot DE, Van der Weijden GA. The prevalence of oral and peri-oral piercings in young adults: a systematic review. Int J Dent Hyg. 2012;10(3):223-8.

5. Chivers L. Body adornment: piercings and tattoos. Nurs Stand. 2002;16:41-5.

6. Peticolas T, Tilliss TS, Cross-Poline GN. Oral and perioral piercing: a unique form of self-expression. J Contemp Dent Pract. 2000;1(3):30-46.

7. Bhatia S, Gupta N, Gupta P, Arora V, Mehta N. Tooth jewellery: Fashion and dentistry go hand in hand. Indian J Dent Adv. 2015;7:263-8.

8. Lo'pez-Jornet P, Camacho-Alonso F, Pons-Fuster JM. A complication of lingual piercing: a case report. Oral Surg Oral Med Oral Pathol Oral Radiol Endod. 2005;99:18-9.

9. Hollowell WH. A new threat to adolescent oral health: the grill. Pediatric Dentistry 29;4:320-2.

10. Neiburger E. A large hypertrophic-keloid lesion associated with tongue piercing: case report. Gen Dent. 2006;54:46-7.

11. Schorzaman CM, Gold MA, Downs JS. Body art; attitudes and practices regarding body piercing among urban undergraduates. J Am Osteopath Assoc. 2007;107:432-8.

12. Monisha N. Dental jewellery - A review. Journal of Pharmacy Research 2018:73-5.

13. Kharat N, Singhai A, Prasant MC, Patil KAK, Ali FM. A tooth tattoo with a purpose: An innovative approach. Journal of Evolution of Medical and Dental Sciences $2014 ; 3(4): 921-5$.

14. Maspero C, Farronato G, Giannini L. Kairyte L, Pisani L, Galbiati G, The complication of oral piercing and the role of dentist in their prevention: A literature review. Stomatologija2014;16:118-24.

15. Soileau KM. Treatment of a mucogingival defect associated with intraoral piercing. J Am Dent Assoc. 2005;136(4):490-4.

16. Nandini DB. Oral piercing and its implications on the health of oral tissues: Aesthetics or mutilation? International Journal of Oral Health Dentistry 2018;4(1):12-6.

17. De Moor RJ, De Witte AM, Delmé KI, De Bruyne MA, Hommez GM, Goyvaerts D. Dental and oral complications of lip and tongue piercings. Br Dent J. 2005;199:506-9.

18. Shacham R, Zaguri A, Librus HZ, Bar T, Eliav E, Nahlieli O. Tongue piercing and its adverse effects. Oral Surg Oral Med Oral Pathol Oral Radiol Endod. 2003;95:274-6.

19. Ehrlich A, Kucenic M, Belsito DV. Role of body piercing in the induction of metal allergies. Am J Contact Dermat. 2001;12:151-5. 
20. Levin L, Zadik Y, Becker T. Oral and dental complications of intra-oral piercing. Dent Traumatol. 2005:21(6):341-3.

21. American Dental Association. ADA Statement on Intraoral/Perioral Piercing. Accessed May 14, 1999 22. Escudero-Castaño N, Perea-García MA, CampoTrapero J, Cano-Sánchez, Bascones-Martínez A. Oral and perioral piercing complications. Open Dent J. 2008;4:133-6.
23.Bhatia S, Arora V, Gupta N, Gupta P, Bansal M, Thakar S. Tooth jewellery-its knowledge and practice among dentists in Tricity, India. J Clin Diagn Res. 2016;10:ZC 32

24. Joys NP, Karuppaiah RM, Garla BK, Taranath M, Pandian RP. "Say Cheese" is Passe', "Say Bling" is HereThe Evolution of Dental Jewelry: A Review. Journal of Advanced Oral Research. 2016;7(3):1-6.

25. Dermata A, Arhakis A. Complications of oral piercing. Balk J Stom. 2013;17:117-21.

Source of support: Nil, Conflict of interest: None declared

Cite this article as:

Parimoo R, Singh B, Sharma D, Sharma V, Javaid A. Oral Ornaments: An Overview. Int Healthc

Res J. 2020;4(6):143-147. https://doi.org/10.26440/IHRJ/0406.09359

\section{AUTHOR AFFILIATIONS: $\left({ }^{*}\right.$ Corresponding Author)}

1. Senior Lecturer, Department of Periodontology, Desh Bhagat Dental College and Hospital, Fatehgarh, Punjab.

[ORCID ID: https://orcid.org/oooo-0002-4200-3854)

2. Prof \& Head, Department of Periodontology, Bhojia Dental College and Hospital, Baddi, Distt. Solan, Himachal Pradesh

3. Postgraduate Student, Department of Periodontology, Bhojia Dental College and Hospital, Baddi, Distt. Solan, Himachal Pradesh

4. Senior Lecturer, Department of Prosthodontics, Bhojia Dental College and Hospital, Baddi, Distt. Solan, Himachal Pradesh 